\title{
veterinary Morbillivirus in common seals stranded on the coasts of Belgium and northern France during summer 1998
}

T. Jauniaux, G. Boseret, F. Coignoul, et al.

Veterinary Record 2001 148: 587-591

doi: 10.1136/vr.148.19.587

Updated information and services can be found at:

http://veterinaryrecord.bmj.com/content/148/19/587

\section{These include: \\ References Article cited in: \\ http://veterinaryrecord.bmj.com/content/148/19/587\#related-urls}

Email alerting Receive free email alerts when new articles cite this article. Sign up in the service box at the top right corner of the online article.

Notes

To request permissions go to:

http://group.bmj.com/group/rights-licensing/permissions

To order reprints go to:

http://journals.bmj.com/cgi/reprintform

To subscribe to BMJ go to:

http://journals.bmj.com/cgi/ep 


\title{
Morbillivirus in common seals stranded on the coasts of Belgium and northern France during summer 1998
}

\author{
T. Jauniaux, G. Boseret, M. Desmecht, J. Haelters, C. ManteCa, J. Tavernier, \\ J. VAN GOMPEL, F. COIGNOUL
}

\begin{abstract}
Sixteen common seals (Phoca vitulina) were stranded on the Belgian and northern French coasts during the summer of 1998. Eleven (10 pups and one adult) were sampled for histopathological, immunohistochemical, serological, bacteriological, parasitological and virological investigations. The main gross findings were severe emaciation, acute haemorrhagic enteritis, acute pneumonia, interstitial pulmonary emphysema and oedema, and chronic ulcerative stomatitis. Microscopical lung findings were acute to subacute pneumonia with interstitial oedema and emphysema. Severe lymphocytic depletion was observed in lymph nodes. Severe acute to subacute meningoencephalitis was observed in one animal. Specific staining with two monoclonal antibodies directed against canine distemper virus (CDV) and phocine distemper virus was observed in a few lymphocytes in the spleen and lymph nodes of three seals. Anti-CDV neutralising antibodies were detected in sera from six animals. Seven of the seals were positive by reverse transcriptasePCR for the morbillivirus phosphoprotein gene. The lesions observed were consistent with those in animals infected by a morbillivirus, and demonstrated that distemper has recently recurred in North Sea seals.
\end{abstract}

Veterinary Record (2001) 148, 587-591

\section{T. Jauniaux, DVM,} G. Boseret, DVM, F. Coignoul, DVM, $\mathrm{PhD}$, Department of Pathology, Veterinary College, Sart Tilman Bat B43, University of Liège, 4000 Liège, Belgium M. Desmecht, DVM, Veterinary and Agrochemical Research Centre, Groeselenberg 99, 1180 Brussels, Belgium J. Haelters, Management Unit of the North Sea Mathematical Models, Royal Belgian Institute of Natural Sciences, $3^{\mathrm{e}}$ and $23^{\mathrm{e}}$ Linieregimeentsplein, 8400 Oostende, Belgium C. Manteca, DVM, Veterinary Centre for Prevention of Animal Diseases, Av Deponthière 40, 4431 Loncin, Belgium J. Tavernier, Royal Belgian Institute of Natural Sciences, Vautierstraat 29, 1000 Brussels, Belgium J. Van Gompel, DVM, Koninginlaan 40, 8370 Blankenberge, and National Sea Life Centre Blankenberge, Belgium
OUTBREAKS of morbillivirus have been responsible for the death of many thousands of marine mammals in various parts of the world. Among pinnipeds, affected populations have been harbour seals (Phoca vitulina) and grey seals (Halichoerus grypus) from the North Sea and the northwestern Atlantic (Kennedy and others 1989, Duigan and others 1993, 1995), Lake Baikal seals (Phoca sibirica) (Grachev and others 1989, Osterhaus and others 1989, Belykh and others 1997), and Caspian seals (Phoca caspica) (Forsyth and others 1998, Kennedy and others 2000). Among cetaceans, morbillivirus lesions were reported in harbour porpoises (Phocoena phocoena) from the coast of Ireland (Kennedy and others 1988, 1991, 1992), bottlenosed dolphins (Tursiops truncatus) from the Atlantic coast of the USA (Lipscomb and others 1994, 1996, Krafft and others 1995), striped dolphins (Stenella coeruleoalba) from the Mediterranean Sea (Domingo and others 1990, 1992, van Bressem and others 1991, Duigan and others 1992) and Atlantic fin whales (Balaenoptera physalus) (Jauniaux and others 1998, 2000).

From April 1988 to the beginning of 1989, approximately 18,000 harbour seals died in northwestern Europe (Kennedy 1990). This epizootic began along the Danish coast and spread to the coasts of Sweden, the Netherlands, Norway, Germany, the UK and Ireland. The morbillivirus responsible for the epizootic was identified as a canine distemper-like virus called phocine distemper virus (PDV). Since early 1989, no cases have been reported in North Sea seals, but serological studies have suggested that PDV infection persisted (Visser and others 1993).

Since 1989, a multidisciplinary research network now called MARIN (Marine Animals Research and Intervention Network) has dealt with the scientific research on marine mammals stranded along the Belgian and northern French coasts or caught as bycatch. It investigates the cause of death of marine mammals and performs toxicological analyses, and it assists in the rescue of marine mammals, live-stranded animals being transported to rehabilitation centres. This paper describes the postmortem observations and the causes of death of seals during an outbreak of disease along the Belgian and northern French coasts during the summer of 1998.

\section{MATERIALS AND METHODS}

Animal collection and postmortem examination Six dead harbour seals and 10 moribund animals were found stranded on the coasts of Belgium and northern France between July 30 and August 28, 1998 (Table 1). The moribund animals were sent to two seal rehabilitation centres (National Sea Life Centre, Blankenberge, Belgium and Zeehondencreche, Pieterburen, the Netherlands) where five of them died within four weeks.

Eleven of the seals were examined postmortem by a standard procedure (Geraci and Lounsbury 1993). Samples for histology and immunohistochemistry were fixed in 10 per cent buffered formalin and samples for virus isolation and reverse transcriptase-PCR (RT-PCR) were kept frozen at $-80^{\circ} \mathrm{C}$ until analysed. From the live animals, samples of lung, intestinal contents, bone marrow and blood were collected asceptically for bacteriological examination, and samples of lung, intestinal contents and liver were taken for parasitology. Only a partial examination was made of any decomposed animals and no samples were taken for histological or microbiological examination.

\section{Histopathology}

Formalin-fixed tissues (spleen, lung, bronchial and mesenteric lymph nodes, brain, intestine, liver, kidney, urinary bladder, adrenal gland, stomach, gonads and any tissues with lesions) were taken from the freshly dead animals, embedded in paraffin, and $5 \mu \mathrm{m}$ sections were stained with haematoxylin and eosin.

\section{Immunochemistry}

A direct immunofluorescence technique was applied to frozen samples of lung and spleen, using an anti-canine distemper virus (CDV) polyclonal antibody (Veterinary and Agrochemical Research Centre, Brussels, Belgium). Blood samples were collected and a virus neutralisation test with $\operatorname{CDV}$ (Appel and Robson 1973), slightly modified for immunofluorescence, was carried out.

An immunoperoxidase technique was applied to samples of lung, spleen, urinary bladder, brain, thymus, mesenteric and bronchial lymph nodes, and selected lesions fixed in for- 
malin, using a mouse monoclonal antibody (mAb) directed against the fusion protein of $\mathrm{CDV}$ (clone 1C5; Biogenesis) and a mAb against the haemagglutinin of PDV (clone 1.3) (Kennedy and others 1989, Trudgett and others 1991). The other reagents were part of a commercial kit using the enhanced polymer one-step staining procedure (Envision; Dako). Tissues from a healthy seal and from a striped dolphin and fin whale infected with morbillivirus were used as negative and positive controls. Test sections, on which the first layer antibody was omitted, served as negative controls.

\section{Virus isolation}

Tissues positive by immunofluorescence were pooled and Vero cells were infected with a 10 per cent tissue suspension. The cell cultures were checked at regular intervals for the presence of cytopathic changes and at each passage (eight days) the cultures were stained with DiffQuick. The supernatant was examined, after negative staining, with a transmission electron microscope (TEM).

\section{RT-PCR}

RNA was extracted from frozen tissues with TriPure isolation reagent (Boehringer Mannheim) following the manufacturer's instructions. From formalin-fixed, paraffin-embedded tissues, RNA was extracted with paraffin block RNA isolation (Ambion). Reverse transcriptase was applied with random hexamers for first strand synthesis. For the PCR, primers were used with frozen and formalin-fixed, paraffin-embedded tissues (Krafft and others 1995). They amplify the morbillivirus phosphoprotein gene, yielding a 78 base-pair product (Krafft and others 1995). The reaction was carried out with the GeneAmp RNA PCR kit (Perkin Elmer, Roche Molecular Systems). The PCR product was analysed by gel electrophoresis on 4 per cent agarose, and the gel was stained with ethidium bromide. A formalin-fixed, paraffin-embedded lymph node from a morbillivirus-infected fin whale was used as positive control material. A formalin-fixed, paraffin-embedded sample of lung from an unaffected animal was used as a negative control, and RT-PCR for beta-actin was carried out as a control for amplifiable RNA (Krafft and others 1995).

\section{RESULTS}

\section{Clinical signs}

The clinical signs recorded during the rehabilitation programme included biphasic hyperthermia, emaciation, weakness, pneumonia with difficult breathing, oculonasal discharges, and gastroenteritis with vomiting and diarrhoea with, in some cases, melaena. Other signs were stomatitis, arthritis, conjunctivitis, external otitis and keratitis. The seals

\begin{tabular}{|c|c|c|c|c|c|c|}
\hline & $\begin{array}{l}\text { Stranding } \\
\text { date }\end{array}$ & $\begin{array}{l}\text { Rehabilitation } \\
\text { period (weeks) }\end{array}$ & Outcome & Sex & $\begin{array}{l}\text { Length } \\
(\mathrm{cm})\end{array}$ & $\begin{array}{l}\text { Weight } \\
\text { (kg) }\end{array}$ \\
\hline Live-stranded & $\begin{array}{l}30 / 07 / 98 \\
09 / 08 / 98 \\
09 / 08 / 98 \\
13 / 08 / 98 \\
26 / 08 / 98 \\
30 / 07 / 98 \\
07 / 08 / 98 \\
08 / 08 / 98 \\
15 / 08 / 98 \\
26 / 08 / 98\end{array}$ & $\begin{array}{c}1 \\
4 \\
4 \\
1 \text { day } \\
1 \\
16 \\
15 \\
15 \\
14 \\
13\end{array}$ & $\begin{array}{l}N \\
N \\
N \\
N \\
N \\
R \\
R \\
R \\
R \\
R\end{array}$ & $\begin{array}{l}M \\
F \\
M \\
F \\
M \\
M \\
M \\
M \\
M \\
F\end{array}$ & $\begin{array}{c}92 \\
93 \cdot 5 \\
100 \\
90 \\
100\end{array}$ & $\begin{array}{r}8.0 \\
12.5 \\
12.6 \\
10.5 \\
11.5 \\
13.5 \\
14.5 \\
15.0 \\
17.0 \\
13.0\end{array}$ \\
\hline Dead-stranded & $\begin{array}{l}12 / 08 / 98 \\
12 / 08 / 98 \\
14 / 08 / 98 \\
14 / 08 / 98 \\
14 / 08 / 98 \\
28 / 08 / 98\end{array}$ & $\begin{array}{l}- \\
- \\
- \\
- \\
- \\
-\end{array}$ & $\begin{array}{l}\mathbf{N} \\
\mathbf{N} \\
\mathbf{N} \\
\mathbf{N} \\
\mathbf{N} \\
\mathbf{N}\end{array}$ & $\begin{array}{l}F \\
M \\
F \\
F \\
M \\
M\end{array}$ & $\begin{array}{l}93 \\
97 \\
92 \cdot 5 \\
92 \\
? \\
?\end{array}$ & $\begin{array}{l}8 \cdot 2 \\
8 \cdot 9 \\
9 \cdot 1 \\
7 \cdot 3 \\
? \\
?\end{array}$ \\
\hline
\end{tabular}

N Necropsied, R Released, M Male, F Female

did not react when approached and were force-fed owing to a lack of appetite. It was suspected that a virus infection was involved because the situation and the syndromes resembled those of the 1988 epizootic of distemper.

The peak of strandings occurred from August 7 to 15, when 11 seals were stranded.

\section{Postmortem examination}

There were 10 pups and one adult (six males and five females) (Table 1). Animals which died during the rehabilitation programme were examined a few hours after death. Other animals were in various states of preservation and four were examined only partially because they were at an advanced stage of decomposition.

The findings are listed in Table 2. The main findings were acute pneumonia and emaciation with little or no fat and muscular atrophy. The lungs failed to collapse and were congested with interstitial and subpleural emphysema. Frothy fluid, containing blood in some cases, was observed in the trachea, bronchi and bronchioles, and the lung parenchyma was wet when sliced. The mucosa of the respiratory tract of many of the animals was congested. One animal had acute pleuritis with a fibrinopurulent exudate in its thoracic cavity and numerous chronic lung abscesses.

A mucopurulent or haemorrhagic nasal discharge was observed in three seals.

In three animals, acute enteritis was observed, with haemorrhagic intestinal contents and enlarged oedematous mesenteric lymph nodes. Acute keratitis was observed in two cases,

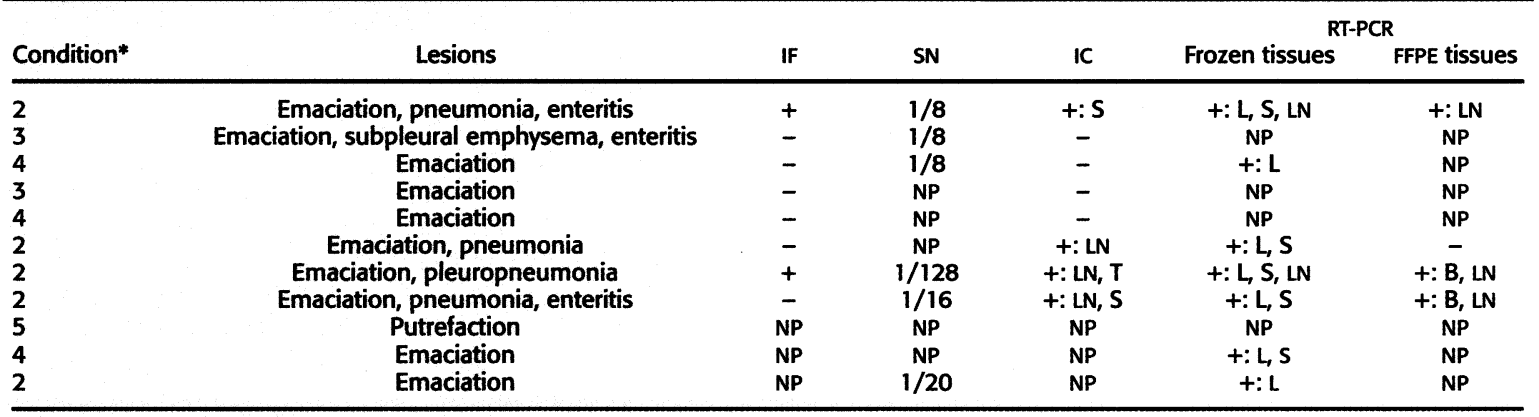

* 2 Very fresh, 3 Moderately decomposed, 4 Severely decomposed

IF Immunofluorescence, SN Seroneutralisation, IC Immunochemistry, RT-PCR Reverse-transcriptase PCR, + Positive result, - Negative result, FFPE Formalin-fixed, paraffin-embedded, L Lung, S Spleen, LN Lymph node, B Brain, T Thymus, NP Not performed 
FIG 1:

Bronchointerstitial pneumonia in a seal with a morbilliviral infection. There were signs of interstitial oedema, congestion and infiltration by mononuclear cells (arrow heads) and a few neutrophils (arrows). Haematoxylin and eosin. Bar $=50 \mu \mathrm{m}$

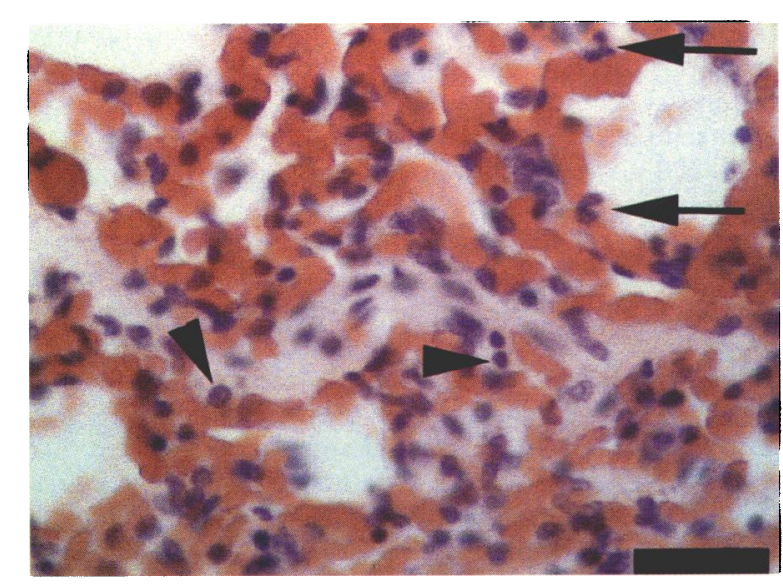

with congestion of periorbital tissue and corneal ulceration in one; ulcerative stomatitis was observed in two animals. In the dead-stranded seals, the gastrointestinal tract was always empty, with no evidence of recent feeding. No respiratory or gastrointestinal parasites were observed.

During its rehabilitation Pseudomonas aeruginosa was isolated from the seal with external otitis. Haemolytic Streptococcus species (group antigen G) was isolated from the lung, the intestine, the eye and the bone marrow of one seal, and Escherichia coli was isolated from the blood, lung and bone marrow of two seals, the findings being consistent with a bacteraemia or septicaemia.

\section{Histopathology}

Three seals had mild subacute bronchointerstitial pneumonia with interstitial oedema, congestion and infiltration by lymphocytes, macrophages and a few neutrophils (Fig 1). In one case small areas of necrosis were observed, associated with colonies of rod-shaped bacteria. Numerous macrophages in the bronchiolar lumen were associated with a serofibrinous exudate. A severe acute necrotising bronchopneumonia in one seal was characterised by the filling of the alveoli and bronchi with an exudate containing neutrophils and large macrophages, and areas of parenchymal necrosis, mainly in a peribronchiolar pattern.

Meningeal congestion was common and was sometimes associated with a mild diffuse infiltration of lymphocytes and macrophages. Acute meningoencephalitis was observed in one animal. The pia mater was thickened by an exudate of macrophages and a few neutrophils, and there were areas of neutrophilic infiltration and neuronal necrosis throughout the cerebrum. There were also haemorrhagic foci disseminated throughout the cerebrum and cerebellum. Perivascular cuffs of macrophages and a few lymphocytes were also disseminated in the cerebral tissue.

In lymphoid tissue (lymph nodes, spleen and thymus), the main findings were lymphoid depletion with an absence of lymphoid follicles, and numerous lymphocytes with pyknotic

\footnotetext{
FIG 3: Lanes 1 and 2 Positive control material, Lanes 3 and 4 Specific 78 base-pair (bp) product amplified from lung (lane 3 ) and lymph node (lane 4), Lanes 5, 6 and 7 No amplification, Lane 850 bp DNA ladder, 4 per cent agarose gel stained with ethidium bromide
}

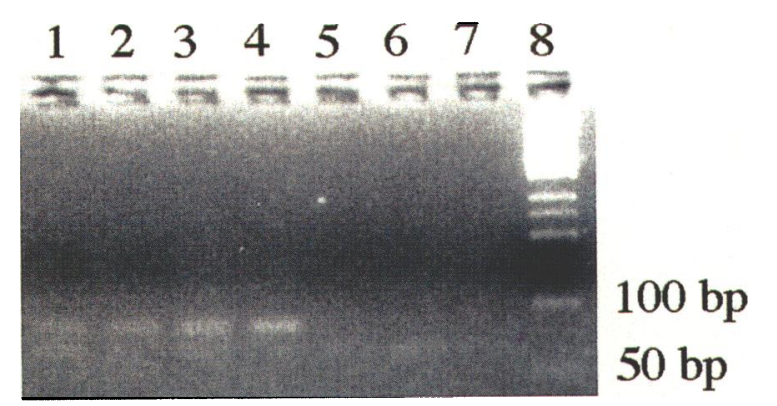

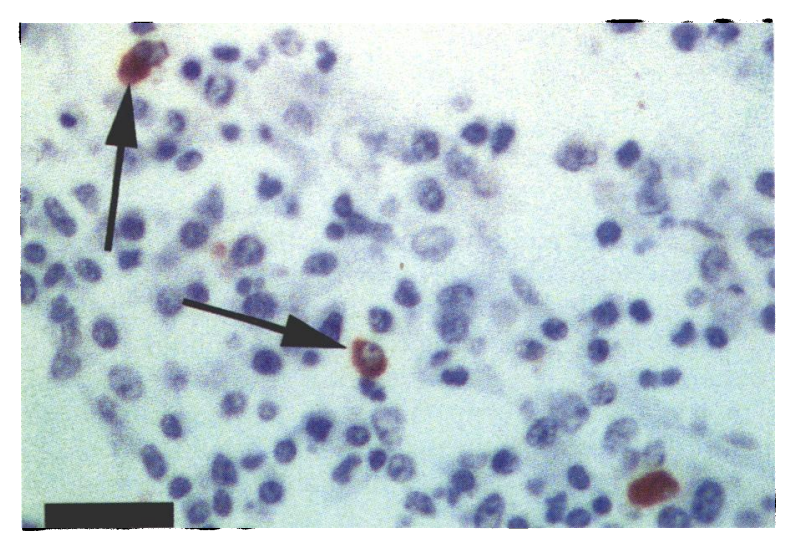

FIG 2: Immunoperoxidase staining for morbillivirus in a lymph node of a seal with a morbiliviral infection. There was a diffuse intracytoplasmic reaction (arrows) in mononuclear cells. Haematoxylin counterstain. Bar $=\mathbf{5 0}$ $\mathrm{mm}$

nuclei. Eosinophilic intranuclear inclusion bodies were occasionally observed. Multinucleated cells were observed in the mesenteric lymph nodes of two seals, in one case associated with granulomas composed of an eosinophilic core of necrotic tissue surrounded by macrophages. Mononuclear cells and eosinophils were frequently observed in the intestinal villi, and submucosal lymphoid follicles were depleted, with lymphocytic necrosis and a prominent fibrous stroma. The liver, kidneys and adrenal glands of many of the animals were congested. In two cases, a mild acute to subacute hepatitis was characterised by neutrophils and an infiltration of macrophages in the liver parenchyma.

Two seals had a severe subacute to chronic stomatitis associated with a superficial necrosis of the submucosal connective tissue. The deep submucosal tissue, under the ulcers, was infiltrated with macrophages, lymphocytes and fibroblasts with vascular thrombi and evidence of new vascularisation. At the edges of the ulcers a few neutrophils were observed within epidermal layers and occasional epithelial cells were vacuolated with small intracytoplasmic inclusions and chromatin margination.

\section{Immunochemistry}

The results of the investigations for morbillivirus infection are shown in Table 2.

Heavy immunofluorescence was detected in lung and spleen tissues from two animals, using an anti-CDV polyclonal antibody. Anti-CDV neutralising antibodies were detected in the sera of six animals, with titres ranging from $1 / 8$ to $1 / 128$.

By immunohistochemistry, there was specific labelling with PDV $1,3 \mathrm{mAb}$ in lymphocytes of lymph nodes, spleen or thymus of three seals and with CDV $1 \mathrm{C} 5 \mathrm{mAb}$ in the spleen of one other seal. Immunoperoxidase labelling was visible as a diffuse intracytoplasmic reaction in mononuclear cells (Fig 2). Intranuclear labelling was observed in a lymph node of one animal.

\section{Virus isolation}

After three passages, syncytial cells were observed after DiffQuick staining, and viral particles typical of a paramyxovirus were observed by negative staining.

\section{RT-PCR}

Fragments of the expected size of about 78 base pairs (Fig 3 ) were generated from various frozen and formalin-fixed, paraffin-embedded tissues (Table 2). Positive results were obtained from seven seals, two of which were moderately to severely decayed and five very well preserved. The fragments were similar to those from the positive control lymph node. 
The RT-PCR was positive for beta-actin but negative for the negative control.

\section{DISCUSSION}

The evidence of a morbillivirus infection in seals stranded along the Belgian and northern French coasts during the summer of 1998 may be summarised as follows: specific immunolabelling was demonstrated in lymphoid tissues of four animals; six seals had serological evidence of infection typical viral particles were observed by TEM after cell culture and finally, specific fragments were amplified by RT-PCR from the tissues of seven seals. By immunohistochemistry and/or RT-PCR investigations, seven seals were considered to be infected by a morbillivirus, but no conclusion could be drawn on the other four. These findings suggest that a morbillivirus disease caused the seal strandings. To the authors' knowledge, this is the first report of morbillivirus disease in harbour seals since the outbreak in $1988 / 89$, and indicates that distemper is still present in the North Sea seal population.

The clinical signs, gross pathological and histological and immunohistological findings were similar to those reported in seal species with a morbillivirus infection (Kennedy and others 1989, Bergman and others 1990, Krogsrud and others 1990, Nunoya and others 1990, Daoust and others 1993, Duignan and others 1993). The infection was confirmed by the isolation of paramyxovirus-like particles in cell culture and by the positive RT-PCR results.

Some of the carcases were putrefied, hampering a diagnosis of morbillivirus. Nevertheless, the RT-PCR analyses revealed the infection in two decomposed seals in which there was no other evidence of infection. When tissue samples are unsuitable for histology and immunohistochemistry, only the amplification of small RNA fragments is appropriate for a diagnosis (Krafft and others 1995).

To compare the morbillivirus characterised so far with other strains known to have affected seals, further investigation using RT-PCR amplification of larger viral RNA sequences of the phosphoprotein gene are in progress (Barrett and others 1993, Taubenberger and others 2000).

Interstitial pneumonia has previously been reported in morbillivirus-infected seals (Kennedy and others 1989 Duignan and others 1993). No pulmonary syncytia with intranuclear inclusion bodies were observed in the samples from these seals, but they are not always reported (Krogsrud and others 1990, Heje and others 1991, Kennedy and others 2000 ); they are observed more frequently in cetaceans than in seals (Domingo and others 1992, Kennedy 1998). The multinucleated cells observed in lymph nodes were consistent with giant cells associated with parasitic larval migration and were not considered as virally induced syncytial cells. The severe lymphoid depletion suggests that the morbillivirus infection caused immunosuppression and secondary diseases such as the three cases of septicaemia. The suppurative bronchopneumonia and encephalitis were also probably caused by secondary bacterial infections.

All the seals were in poor body condition, as indicated by the small quantities of subcutaneous or abdominal fat and the atrophy of the dorsal muscles. Similar signs of wasting have been reported in other morbillivirus-infected seals (Forsyth and others 1998) and cetaceans (Duignan and others 1992, Kennedy and others 1992).

During the summer of 1998,11 seals were found dead in less than one month, whereas between 1990 and 1997, only six seals had been found dead in the same area (T. Jauniaux, unpublished observations). With the exception of one animal, they were all pups around eight weeks old. At this age there is often a loss of passively acquired maternal PDV-neutralising antibodies, leading to an increased susceptibility to PDV infec- tion (Harder and others 1993). In addition, Visser and others (1993) reported that six pups died of phocine distemper within two weeks of birth, while their parents showed no signs of infection, corresponding with the present observation of a lack of disease in adult seals. At this age, weaning is an additional predisposing factor.

Because juvenile seals become more susceptible to PDV infections after the loss of their passively acquired maternal immunity, Harder and others (1993) suggested that there would be an increase in the number of PDV-susceptible seals in the North Sea in animals born after 1989. In addition, the majority of the seal population in the Dutch Wadden Sea had morbillivirus-specific antibodies and it was suspected that active PDV infections would continue to occur in that area (Visser and others 1993). Indeed, juvenile seals (three months to one year old) which had lost their maternal antibodies and were sampled in the Wadden Sea in 1992, had morbillivirusspecific antibodies. It is believed that a morbillivirus infection can persist in small groups without evidence of disease (Visser and others 1993). The present results support the hypothesis that PDV has continued to circulate in the North Sea since 1989.

Earlier observations of marked seals showed that most of the seals on the Belgian coast originated from the east coast of England, especially from the Wash. In 1998, this was confirmed indirectly because there was an abnormally high mortality of seal pups in the Wash during the summer (Van Gompel 1999). Unfortunately, these pups were not examined postmortem.

The evidence suggests that morbillivirus infections circulate in the North Sea seal population, as in many other marine mammal species around the world. Monitoring programmes such as MARIN should investigate the causes of death of pinnipeds and cetaceans, in addition to monitoring their immune status. Such investigations should help to determine the susceptibility of marine mammal populations to specific diseases.

\section{ACKNOWLEDGEMENTS}

The authors thank A. Lastavel for collecting and providing the animals. They also acknowledge $M$. Domingo for providing the tissues of a morbillivirus-infected dolphin, A. Trudgett for the mAb to the PDV, and A. Villers, M. Sarlet, M. P. Desmecht and F. Verdebout for technical assistance. The authors are very grateful to E. Thiry for stimulating discussions and useful comments on the manuscript. This work was funded by the Belgian State - Prime Minister's Service, Office for Scientific, Technical and Cultural Affairs (MN/DD/51).

\section{References}

APPEL, M. \& ROBSON, D. S. (1973) A microneutralization test for canine distemper virus. American Journal of Veterinary Research 34, 1459-1463 BARRETT, T., VISSER, I. K. G., MAMAEV, L., GOATLEY, L., VAN BRESSEM, M-F. \& OSTERHAUS, A. D. M. E. (1993) Dolphin and porpoise morbilliviruses are genetically distinct from phocine distemper virus. Virology New York 193, 1010-1021

BELYKH, O., GOLDBERG, O., LIKHOSHWAY, Y. \& GRACHEV, M. (1997) Light, electron and immunoelectron microscopy of organs from seals of Lake Baikal sampled during the morbillivirus infection of 1987-1988. European Journal of Veterinary Pathology 3, 133-145

BERGMAN, A., JARPLID, B. \& SVENSSON, B. M. (1990) Pathological findings indicative of distemper in European seals. Veterinary Microbiology 23, 331341

DAOUST, P-Y., HAINES, D. M., THORSEN, J., DUIGNAN, P. J. \& GERACI, J. R. (1993) Phocine distemper in a harp seal (Phoca groenlandica) from the gulf of St Lawrence, Canada. Journal of Wildlife Diseases 29, 114-117

DOMINGO, M., FERRER, L., PUMAROLA, M., MARCO, A. I., PLANA, J. KENNEDY, S., MCALISKEY, M. \& RIMA, B. K. (1990) Morbillivirus in dolphins. Nature 348, 21 
DOMINGO, M. VISA, J., PUMAROLA, M., MARCO, A. J., FERRER, L., RABANAL, R. \& KENNEDY, S. (1992) Pathologic and immunocytochemical studies of morbillivirus infection in striped dolphins (Stenella coeruleoalba). Veterinary Pathology 29, 1-10

DUIGNAN, P. J., GERACI, J. R., RAGA, J. A. \& CALZADA, N. (1992) Pathology of morbillivirus infection in striped dolphins (Stenella coeruleoalba) from Valencia and Murcia, Spain. Canadian Journal of Veterinary Research 56, 242-248 DUIGNAN, P. J., SADOVE, S., SALIKI, J. T. \& GERACI, J. R. (1993) Phocine distemper in harbour seals (Phoca vitulina) from Long Island, New York. Journal of Wildlife Diseases 29, 465-469

DUIGNAN, P. J., SALIKI, J. T., ST AUBIN, D. J., EARLY, G., SADOVE, S., HOUSE, J. A., KOVACS, K. \& GERACI, J. R. (1995) Epizootiology of morbillivirus infection in North American harbour seals (Phoca vitulina) and gray seals (Halichoerus grypus). Journal of Wildlife Diseases 31, 491-501

FORSYTH, M. A., KENNEDY, S., WILSON, S., EYBATOV, T. \& BARRETT, T. (1998) Canine distemper virus in a Caspian seal. Veterinary Record 143, 662664

GERACI, J. R. \& LOUNSBURY, V. J. (1993) Marine Mammals Ashore: A Field Guide for Strandings. Galveston, Texas A\&M Sea Grant Publication. pp 133143

GRACHEV, M., KUMAREV, V. P., MAMAEV, L. V., ZORIN, V. L., BARANOVA L. V., DENIKINA, N. N., BELIKOV, S. I., PETROV, E. A., KOLESNIK, V. S., KOLESNIK, R. S., DOROFEEV, V. M., BEIM, A. M., KUDELIN, V. N., NAGEIVA, F. G. \& SIDOROV, V. M. (1989) Distemper virus in Baikal seals. Nature 338, 209

HARDER, T. C., STEDE, M., WILLHAUS, T., SCHWARZ, J., HEIDEMANN G. \& LIESS, B. (1993) Morbillivirus antibodies of maternal origin in harbour seal pups (Phoca vitulina). Veterinary Record 132, 632-633

HEJE, N-I., HENRIKSEN, P. \& AALBOEK, B. (1991) The seal death in Danish waters 1988 1. Pathological and bacteriological studies. Acta Veterinaria Scandinavica 32, 205-210

JAUNIAUX, T., CHARLIER, G., DESMECHT, M. \& COIGNOUL, F. (1998) Lesions of morbillivirus infection in a fin whale (Balaenoptera physalus) stranded along the Belgian coast. Veterinary Record 143, 423-424

JAUNIAUX, T., CHARLIER, G., DESMECHT, M., HAELTERS, J., JACQUES, T., LOSSON, B., VAN GOMPEL, J., TAVERNIER, J. \& COIGNOUL, F. (2000) Pathological findings in two fin whales (Balaenoptera physalus) with evidence of morbillivirus infection. Journal of Comparative Pathology 123, 198-201

KENNEDY, S. (1990) A review of the 1988 European seal morbillivirus epizootic. Veterinary Record 127, 563-567

KENNEDY, S. (1998) Morbillivirus infections in aquatic mammals. Journal of Comparative Pathology 119, 201-225

KENNEDY, S., KUIKEN, T., JEPSON, P. D., DEAVILLE, R. C., FORSYTH, M. A., BARRETT, T., VAN DE BILDT, M. W. G., OSTERHAUS, A. D. M. E., EYBATOV, T., DUCK, A., KYDYRMANOV, A., MITROFANOV, I. \& WIL SON, S. (2000) Mass die-off of Caspian seals caused by canine distemper virus. Emerging Infectious Diseases 6, 637-639

KENNEDY, S., KUIKEN, T., ROSS, H. M., MCALISKEY, M., MOFFETT, D. MCNIVEN, C. M. \& CAROLE, M. (1992) Morbillivirus infection in two common porpoises (Phocoena phocoena) from the coasts of England and Scotland. Veterinary Record 131, 286-290

KENNEDY, S., SMYTH, J. A., CUSH, P. F., DUIGNAN, P. J., PLATTEN, M. MCCULLOUGH, S. J. \& ALLAN, G. M. (1989) Histopathologic and immunocytochemical studies of distemper in seals. Veterinary Pathology 26, 97-103

KENNEDY, S., SMYTH, J. A., CUSH, P. F., MCALISKEY, M., MCCULLOUGH S. J. \& RIMA, B. K. (1991) Histopathological and immunocytochemical studies of distemper in harbour porpoises. Veterinary Pathology 28, 1-7

KENNEDY, S., SMYTH, J. A., CUSH, P. F., MCCULLOUGH, S. J., ALLAN, G. M. \& MCQUAID, S. (1988) Viral distemper now found in porpoises. Nature 336, 21

KRAFFT, A., LICHY, J. H., LIPSCOMB, T. P., KLAUNBERG, B. A., KENNEDY S. \& TAUBENBERGER, J. K. (1995) Postmortem diagnosis of morbillivirus infection in bottlenose dolphins (Tursiops truncatus) in the Atlantic and Gulf of Mexico epizootics by polymerase chain reaction-based assay. Journal of Wildlife Diseases 31, 410-415

KROGSRUD, J., EVENSEN, O., HOLT, G., HOIE, S. \& MARKUSSEN, N. H. (1990) Seal distemper in Norway in 1988 and 1989. Veterinary Record 126 460-461

LIPSCOMB, T. P., KENNEDY, S., MOFFETT, D., KRAFFT, A., KLAUNBERG B. A., LICHY, J. H., REGAN, G. T., WORTHY, G. A. J. \& TAUBENBERGER J. K. (1996) Morbilliviral epizootic in bottlenose dolphins of the gulf of Mexico. Journal of Veterinary Diagnostic Investigations 8, 283-290

LIPSCOMB, T. P., SCHULMAN, F. Y., MOFFETT, D. \& KENNEDY, S. (1994) Morbilliviral disease in Atlantic bottlenose dolphins (Tursiops truncatus) from the 1987-1988 epizootic. Journal of Wildlife Diseases 30, 567-57

NUNOYA, T., TAJIMA, M., ISHIKAWA, Y., SAMEJIMA, T., ISHIKAWAA, H. \& HASEGAWA, K. (1990) Occurrence of a canine distemper-like disease in aquarium seals. Japanese Journal of Veterinary Science 52, 469-477

OSTERHAUS, A. D. M. E., GROEN, J., UYTDEHAAG, D. G. C. M., VISSER, I. K. G., VAN DE BILDT, M. W. G., BERGMAN, A. \& KLINGEBORN, B. (1989) Distemper virus in Baikal seals. Nature 339, 209-210

TAUBENBERGER, J. K., TSAI, M., ATKIN, J., FANNING, T. G., KRAFFT, A. MOELLER, R. B., KODSI, S. E., MENSE, M. G. \& LIPSCOMB, T. P. (2000) Molecular genetic evidence of a novel morbillivirus in a long-finned pilot whale (Globicephalus melas). Emerging Infectious Diseases 6, 42-45

TRUDGETT, A., LYONS, C., WELSH, M. J., DUFFY, N., MCCULLOUGH, S. J. \& MCNEILLY, F. (1991) Analysis of a seal and a porpoise morbillivirus using monoclonal antibodies. Veterinary Record 128,61

VAN BRESSEM, M-F., VISSER, I. K. G., VAN DE BILDT, M. W. G., TEPPEMA, J. S., RAGA, J. A. \& OSTERHAUS, A. D. M. E. (1991) Morbillivirus infection in Mediterranean striped dolphins (Stenella coeruleoalba). Veterinary Record $129,471-472$

VAN GOMPEL, J. (1999) Zeehondenvirus aan de Belgische kust in 1998. Zoogdier 10, 16-18

VISSER, I. K. G., VEDDER, E. J., VOS, H. W., VAN DE BILDT, M. W. G. \& OSTERHAUS, A. D. M. E. (1993) Continued presence of phocine distemper virus in the Dutch Wadden Sea seal population. Veterinary Record 133, 320-322

\section{ABSTRACTS}

\section{Dental disease in chinchillas}

DENTAL abnormalities, particularly elongation of teeth, were detected in 35 per cent of 651 apparently healthy chinchillas. There were abnormalities of the incisors in 31 of 56 chinchillas examined because they were ill, and in all but one case they were secondary to crown elongation of the cheek teeth or to the absence of opposing teeth, rather than being a primary skeletal problem. The clinical signs commonly attributed to malocclusion were not exclusively due to malocclusion but were also associated with coronal spike formation, root elongation and advanced periodontal lesions. Caries and resorptive lesions rarely caused clinical signs, but were identified in 37 per cent of postmortem examinations. The elongation of the teeth is probably due to lack of attrition from the diet, and could be prevented by feeding a diet more closely matching the diet of the animals in the wild.

CROSSLEY, D. A. (2001) Dental disease in chinchillas in the UK. Journal of Small Animal Practice 42, 12-19

\section{Prevalence of Chagas disease in dogs in Oklahoma}

A VETERINARIAN was exposed to the risk of infection by Trypanosoma cruzi as a result of an accidental needle stick involving blood and lymph from an infected dog. A serological survey of 301 dogs was therefore conducted, using a radio-immunoprecipitation assay, to determine the prevalence of the infection in dogs in Oklahoma. Eleven $(3.6 \mathrm{per}$ cent) of the dogs were seropositive for $T$ cruzi; 10 of them were hunting dogs, and six had clinical signs consistent with $T$ cruzi infection. Protozoal organisms were isolated from the blood of one of the seropositive dogs and identified as $T$ cruzi by means of a PCR assay.

BRADLEY, K. K., BERGMAN, D. K., WOODS, J. P., CRUTCHER, J. M. \& KIRCHHOFF, L.V. (2000) Prevalence of American trypanosomiasis (Chagas disease) among dogs in Oklahoma. Journal of the American Veterinary Medical Association 217, 1853-1857 